\title{
KONSENTRASI KARBON MONOKSIDA DAN NITROGEN DIOKSIDA PADA RUAS JALAN KUIN UTARA DAN KUIN SELATAN KOTA BANJARMASIN
}

\author{
CONCENTRATION OF CARBON MONOXIDE AND NITROGEN DIOXIDE IN THE ROAD \\ OF NORTH KUIN AND SOUTH KUIN BANJARMASIN CITY
}

\author{
$\frac{\text { Dwi Putri Agustina }{ }^{1} \text {,Nova Annisa }{ }^{2}, \text { Rony Riduan }{ }^{3}, \text { Hafiizh Prasetia }}{4}$ \\ Program Studi Teknik Lingkungan Fakultas Teknik ULM, \\ Jl. A. Yani Km.37, Banjarbaru, Kode Pos 70714, Indonesia \\ E-mail: aiyuvasha@ulm.ac.id
}

\begin{abstract}
ABSTRAK
Sektor transportasi menjadi salah satu sumber pencemaran udara tertinggi di Indonesia. Karbon monoksida $(\mathrm{CO})$ dan nitrogen dioksida $\left(\mathrm{NO}_{2}\right)$ adalah pencemaran udara yang bersumber dari aktivitas kendaraan bermotor akibat pembakaran mesin yang tidak sempurna. Berdasarkan studi observasi, ruas jalan Kuin Utara dan Kuin Selatan memiliki tingkat aktivitas lalu lintas yang padat dimana kendaraan yang melintas tidak sesuai dengan fungsi jalan yang seharusnya yaitu berdasarkan SK Walikota Banjarmasin No 548 Tahun 2017 ruas jalan di kelurahan kuin merupakan jalan lingkungan sekunder. Dampak yang ditimbulkan dari aktivitas transportasi adalah menghambat proses fotosintesis dan penyakit ISPA. Penelitian ini bertujuan untuk mengetahui konsentrasi karbon monoksida dan nitrogen dioksida pada wilayah studi dan dibandingkan dengan baku mutu Peraturan Gubernur Kalimantan Selatan No 53 Tahun 2007. Penelitian dilakukan selama 2 hari pada hari Minggu mewakili hari libur dan pada hari Senin mewakili hari kerja dengan melakukan pengukuran udara ambien pada 3 titik sampling di wilayah studi. Pengambilan sampel dilakukan pada pagi, siang dan sore hari. Parameter yang diukur adalah CO dan NO2. Pengukuran konsentrasi CO mengacu pada SNI 19-7119.7-2005 dan pengukuran konsentrasi NO2 mengacu pada SNI 19-7119.2-2017. Hasil pengukuran dilapangan pada hari Minggu diperoleh konsentrasi CO tertinggi di titik 1 pada pagi hari sebesar $824 \mu \mathrm{g} / \mathrm{m} 3$ dan konsentrasi NO2 tertinggi di titik 2 pada siang hari sebesar 136,7 $\mu \mathrm{g} / \mathrm{m} 3$. Hasil pengukuran dilapangan pada hari Senin diperoleh konsentrasi CO tertinggi di titik 3 pada pagi hari sebesar $2.358 \mu \mathrm{g} / \mathrm{m} 3$ dan konsentrasi $\mathrm{NO}_{2}$ tertinggi di titik 2 pada siang hari sebesar 44,6 $\mu \mathrm{g} / \mathrm{m}^{3}$.
\end{abstract}

Kata Kunci: $\quad$ Karbon Monoksida, Nitrogen Dioksida, Transportasi, Kuin.

\section{ABSTRACT}

The transportation sector is one of the highest sources of air pollution in Indonesia. Carbon monoxide $(\mathrm{CO})$ and nitrogen dioxide (NO2) are air pollution that comes from motor vehicle activities due to incomplete combustion of engines. Based on observational studies, the North Kuin and South Kuin roads have a high level of traffic activity where the passing vehicles do not match the proper road functions, namely based on the Mayor of Banjarmasin Decree No. 548 in 2017 the roads in Kuin are secondary roads. The impact of transportation activities is to inhibit photosynthesis and ARI disease. This study aims to determine the concentration of carbon monoxide 
and nitrogen dioxide in the study area and compared with the quality standards of Governor of South Kalimantan Regulation No. 53 of 2007. The study was conducted for 2 days on Sundays representing holidays and on Mondays representing working days by taking air measurements ambient at 3 sampling points in the study area. Sampling is done in the morning, afternoon and evening. The parameters measured were $\mathrm{CO}$ and NO2. Measurement of CO concentration refers to SNI 19-7119.7-2005 and measurement of NO2 concentration refers to SNI 19-7119.2-2017. The results of measurements in the field on Sunday obtained the highest CO concentration at point 1 in the morning at $824 \mu \mathrm{g} / \mathrm{m} 3$ and the highest NO2 concentration at point 2 during the day was 136.7 $\mu \mathrm{g} / \mathrm{m3}$. The results of measurements in the field on Monday obtained the highest CO concentration at point 3 in the morning at 2,358 $\mu \mathrm{g} / \mathrm{m} 3$ and the highest NO2 concentration at point 2 during the day was $44.6 \mu \mathrm{g} / \mathrm{m} 3$.

Keywords: Carbon Monoxide, Nitrogen Dioxide, Transportation, Kuin.

\section{PENDAHULUAN}

Perkembangan teknologi yang pesat di daerah perkotaan sangat berkaitan dengan permasalahan lingkungan yang ditimbulkan, salah satunya adalah terjadi pencemaran udara (Bachtiar, 2013). Tercemarnya udara bersumber dari sektor transportasi, perindustrian, dan kegiatan rumah tangga. Sumber pencemaran yang dominan di kota-kota besar berasal dari sektor transportasi. Sektor transportasi terbukti menyumbang pencemaran udara tertinggi di Indonesia sekitar $85 \%$ (Roza, Ilza, \& Anita, 2015) Sektor transportasi merupakan sumber pencemaran yang bergerak meliputi mobil, truk, bus, motor, pesawat, dan kapal (Kepmenlh, 2013). Penggunaan bahan bakar minyak (BBM) oleh sektor transportasi diketahui dapat menimbulkan dampak besar terhadap lingkungan. Menurut Kementerian Lingkungan Hidup Tahun 2012 , polusi udara yang berasal dari kendaraan bermotor menyumbang 70,5\% Karbon Monoksida, 18,34\% Hidrokarbon, 8,89\% Oksida Nitrogen, 1,33\% Partikulat, dan. $0,88 \%$ Oksida Sulfida.

Gas karbon monoksida (CO) merupakan suatu gas yang sangat beracun, tidak berbau, tidak berwarna dan mudah terbakar. Karbon monoksida berasal dari sisa tidak sempurnanya pembakaran kendaraan bermotor. Jika terhirup oleh manusia gas karbon monoksida sangat berbahaya.karena akan mengikat oksigen yang berkaitan dengan hemoglobin pada darah. Apabila tubuh kekurangan oksigen maka dapat menyebabkan sesak dan menyebabkan kematian (Arifiyanti, 2013). Semakin tinggi konsentrasi karbon monoksida yang terhirup oleh manusia maka semakin tinggi resiko yang diterima oleh manusia tersebut (Damara, Wardhana, \& Sutrisno, 2017). Terjadinya kemacetan lalu lintas dapat meningkatkan konsentrasi pencemar ke udara ambien, kontribusi terbesar karbon monoksida di udara ambien adalah kendaraan bermotor (Harahap, Marsaulina, \& Ashar, 2013).

Nitrogen dioksida $\left(\mathrm{NO}_{2}\right)$ adalah gas yang sangat beracun dibandingkan dengan jenis nitrogen oksida lain di udara. Dampak paparan konsentrasi $\mathrm{NO}_{2}$ pada manusia dapat menimbulkan berbagai penyakit. Organ tubuh yang paling peka terhadap pencemaran yang diakibatkan oleh gas $\mathrm{NO}_{2}$ adalah paru-paru, dimana akan terjadi pembengkakan yang menyebabkan penderita sulit bernapas (Herawati, Riyanti, \& Pratiwi, 2018). Karakteristik gas $\mathrm{NO}_{2}$ di udara ambien berasal dari baunya yang sangat tajam dan berwarna merah kecoklatan. Dibandingkan dengan gas $\mathrm{NO}$, gas $\mathrm{NO}_{2}$ memiliki sifat yang lebih toksik. Konsentrasi nitrogen dioksida $\left(\mathrm{NO}_{2}\right)$ di kota berkembang umumnya lebih tinggi dibandingkan daerah pedesaan, hal tersebut diakibatkan karena tingkat aktivitas manusia di daerah perkotaan lebih tinggi dibanding pedesaan yang akan meningkatkan konsentrasi nitrogen dioksida $\left(\mathrm{NO}_{2}\right)$ di udara ambien salah satunya aktivitas transportasi (Harahap et al., 2013). 
Berdasarkan hasil studi observasi, jalan Kuin Utara dan Kuin Selatan berada di kawasan padat pemukiman dan ruas jalan di daerah tersebut memiliki arus lalu lintas yang cukup padat karena ruas jalan di kelurahan Kuin Utara dan Kuin Selatan merupakan jalan penghubung dengan daerah lain, selain itu daerah tersebut merupakan kawasan pariwisata dan berdekatan dengan kawasan industri sehingga ruas jalan tersebut menjadi jalur utama wisatawan dan karyawan industri, sehingga sering menimbulkan kemacetan di beberapa ruas jalan. Selain itu keberadaan sungai kuin menjadi salah satu denyut nadi kehidupan masyarakat, karena sampai saat ini sungai kuin masih menjadi jalur transportasi sehari-hari dalam mobilitas atau sebagai transportasi pengangkutan komoditas. Sungai kuin juga merupakan salah satu objek wisata sungai di Banjarmasin yang para pengunjungnya baik lokal maupun mancanegara. Jenis angkutan sungai yang ada di sungai kuin termasuk jenis angkutan kapal bermotor yang digerakkan oleh mesin berbahan bakar solar (Sari, 2008). Menurut Fariya \& Rejeki, (2015), penghasil emisi gas karbon karbon monoksida terbesar kedua yaitu berasal dari proses pembakaran bahan bakar oleh kapal bermotor berbahan bakar solar.

Berdasarkan latar belakang diatas dan didukung dengan data puskesmas S. Parman menunjukan penyakit terbanyak kedua pada tahun 2017 yaitu penyakit ISPA sebesar 2026 jiwa maka penelitian ini bertujuan untuk mengetahui konsentrasi gas karbon monoksida (CO) dan gas nitrogen dioksida $\left(\mathrm{NO}_{2}\right)$ pada ruas jalan Kuin Utara dan Kuin Selatan Kota Banjarmasin dibandingkan dengan baku mutu "Peraturan Gubernur Kalimantan Selatan No 53 Tahun 2007".

\section{METODE PENELITIAN}

\subsection{Lokasi dan Waktu Penelitian}

Penelitian ini dilaksanakan di 3 titik di Jl. Kuin Utara dan Jl. Kuin Selatan pada tanggal 5 Agustus 2018 dan 6 Agustus 2018. Lebih jelasnya dapat dilihat pada peta lokasi penelitian sebagai berikut :

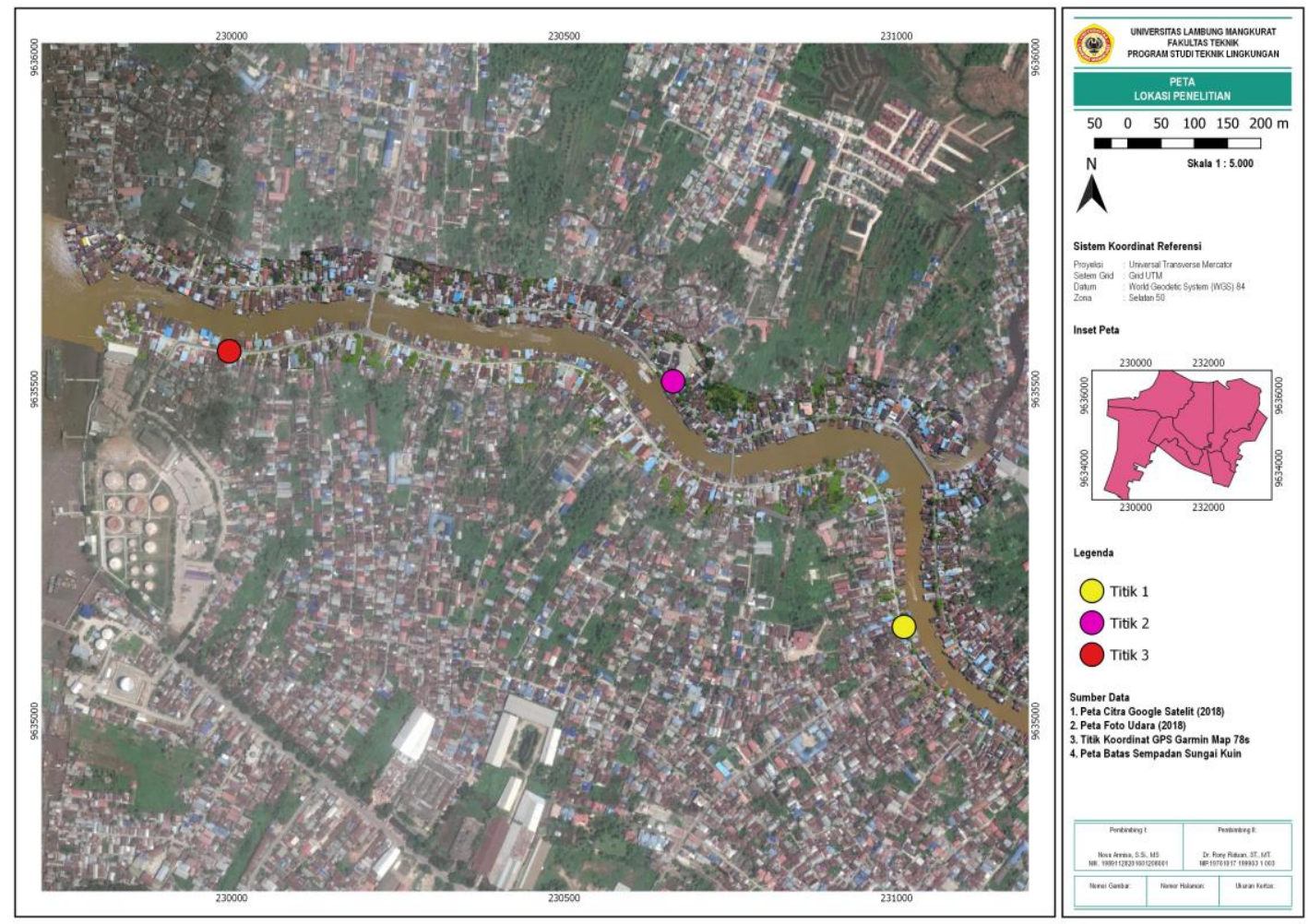


Gambar 1. Lokasi Penelitian

\subsection{Alat dan Bahan Penelitian}

Alat yang digunakan pada penelitian ini berupa anemometer, thermometer, spektrofotometer, NDIR Analyzer, pompa angin dan GPS Garmin 78s. Bahan yang dibutuhkan pada penelitian ini yaitu alat tulis, Tedlar bag.

\subsection{Rancangan Penelitian}

Penelitian ini memiliki tiga tahapan pelaksanaan. Tahap pertama adalah studi literatur dan survey pendahuluan, dalam tahap survey pendahuluan dilakukan penentuan titik lokasi pengambilan sampel karbon monoksida di udara ambien berdasarkan "SNI 19-7119.9-2005" yaitu :

a. Menempatkan peralatan di daerah terbuka (gedung atau bangunan yang rendah dan saling berjauhan)

b. Penempatan peralatan berjarak $1 \mathrm{~m}$ sampai $5 \mathrm{~m}$ dari pinggir jalan yang akan diambil contoh uji dan pada ketinggian 1,5 m sampai dengan $3 \mathrm{~m}$ dari permukaan jalan.

Dari survey pendahuluan, didapatkan 3 titik yaitu 1 titik berada di ruas jalan Kuin Utara dan 2 titik di ruas jalan Kuin Selatan, Tahap kedua melakukan pengukuran karbon monoksida di udara ambien berdasarkan "SNI 7119.10-2011", metode ini digunakan untuk cara uji kadar karbon monoksida udara ambien menggunakan metode NDIR (Non Dispersive Infra Red), selanjutnya pengukuran nitrogen dioksida di udara ambien berdasarkan "SNI 19-7119.2-2017", metode ini digunakan untuk penentuan nitrogen dioksida $\left(\mathrm{NO}_{2}\right)$ di udara ambien menggunakan metode Griess Saltzman secara spektrofotometri. Pengukuran konsentrasi $\mathrm{CO}$ dan $\mathrm{NO}_{2}$ dilakukan selama 1 jam. Pengukuran konsentrasi pada setiap titik dilakukan selama 2 hari, pada hari Minggu perwakilan hari libur dan hari Senin perwakilan hari kerja. Pengukuran dilakukan sebanyak 3 kali yaitu pada pagi, siang dan sore hari. Tahap terakhir yaitu analisis data yang didapatkan selanjutnya dibandingkan dengan baku mutu "Peraturan Gubernur Kalimantan Selatan No 53 Tahun 2007 tentang baku mutu udara ambien dan kebisingan".

\subsection{Analisis Data}

Analisis data dilakukan secara deskriptif dengan mengetahui hasil pengukuran di titik pengamatan kemudian dibandingkan dengan baku mutu "Peraturan Gubernur Kalimantan Selatan no 53 tahun 2007 tentang Kebisingan dan Pencemar Udara".

\section{HASIL DAN PEMBAHASAN}

\subsection{Kondisi Meteorologis}

Tujuan dilakukan pengukuran meteorologi adalah untuk mengetahui kondisi meteorologis pada saat dilakukannya pengukuran konsentrasi gas karbon monoksida dan nitrogen dioksida di lapangan. Berikut ini tabel 1 dan tabel 2 data suhu dan kecepatan angin :

Tabel 1. Hasil Pengukuran Minggu 5 Agustus 2018

\begin{tabular}{ccccc}
\hline Parameter & Lokasi & \multicolumn{3}{c}{ Waktu Pengukuran } \\
& & Pagi & Siang & Sore \\
\hline \multirow{2}{*}{ Suhu $\left({ }^{\circ} \mathrm{C}\right)$} & I & 29.4 & 31.2 & 31.6 \\
& II & 32.2 & 34.8 & 31.8 \\
& III & 28.9 & 35.4 & 33.1 \\
\hline Kecepatan & I & 0.77 & 1.98 & 1.05
\end{tabular}




\begin{tabular}{ccccc}
\hline Parameter & Lokasi & \multicolumn{3}{c}{$\begin{array}{c}\text { Waktu Pengukuran } \\
\text { Siang }\end{array}$} \\
\cline { 2 - 5 } Angin $(\mathrm{m} / \mathrm{s})$ & & Pagi & Sore \\
\cline { 2 - 5 } & III & 3.45 & 3.49 & 4.34 \\
Kelembaban & I & 64 & 0.81 & 0.76 \\
(\% RH) & II & 45 & 59 & 57 \\
III & 74 & 38 & 51 \\
\end{tabular}

Tabel 2. Hasil Pengukuran Senin 6 Agustus 2018

\begin{tabular}{ccccc}
\hline Parameter & Lokasi & Pagi & $\begin{array}{c}\text { Waktu Pengukuran } \\
\text { Siang }\end{array}$ & Sore \\
\hline \multirow{2}{*}{ Suhu $\left({ }^{\circ} \mathrm{C}\right)$} & I & 26.2 & 31.2 & 30.2 \\
& II & 32.2 & 35.2 & 31.1 \\
& III & 28 & 37.1 & 29.5 \\
\hline Kecepatan & I & 0.36 & 0.98 & 0.61 \\
Angin $(\mathrm{m} / \mathrm{s})$ & II & 0.07 & 1.79 & 1.27 \\
& III & 0.13 & 0.19 & 0.12 \\
\hline Kelembaban & I & 57 & 59 & 59 \\
$(\% \mathrm{RH})$ & II & 62 & 35 & 52 \\
\hline
\end{tabular}

Berdasarkan hasil pengukuran pada hari Minggu dan hari Senin dapat pada tabel 1 dan tabel 2, diketahui perbedaan suhu pada waktu pagi, siang dan sore di tiga lokasi penelitian dimana suhu tertinggi di hari Minggu pada pagi hari dititik 2 sebesar $33^{\circ} \mathrm{C}$ kemudian siang hari tertinggi berada titik 3 dimana yaitu $35,4^{\circ} \mathrm{C}$ dan pada sore hari pada titik 3 sebesar $33,1^{\circ} \mathrm{C}$. Pengukuran suhu pada hari Senin menunjukan suhu tertinggi pada pagi hari berada pada titik 2 yaitu $32,2^{\circ} \mathrm{C}$ kemudian pada siang hari suhu tertinggi di titik $336^{\circ} \mathrm{C}$ dan pada sore hari titik 2 memiliki suhu tertinggi yaitu $31,1^{\circ} \mathrm{C}$. Perbedaan suhu ini disebabkan oleh beberapa faktor diantaranya kemiringan jatuhnya sinar matahari dan keadaan awan. Pada siang hari sudut jatuh sinar matahari lebih tegak lurus dibandingkan sudut jatuh matahari pada pagi dan sore hari sehingga radiasi matahari yang diterima pada siang hari lebih besar dibandingkan pagi dan sore hari, akibatnya suhu pada siang hari akan lebih tinggi dibandingkan pada pagi dan sore hari (Goembira, Surianti, \& Ihsan, 2014).

Pengukuran kecepatan angin di hari Minggu, lokasi yang memiliki nilai kecepatan angin tertinggi pada pagi, siang dan sore hari adalah titik 2 masing-masing sebesar 3,45 m/s 3,49 m/s 4,34 m/s. Hasil pengukuran kecepatan angin hari Senin menunjukan titik 1 memiliki kecepatan angin yang tinggi pada pagi hari yaitu $0,37 \mathrm{~m} / \mathrm{s}$ kemudian pada siang hari di titik 2 sebesar $1,79 \mathrm{~m} / \mathrm{s}$ dan pada sore hari kecepatan angin tertinggi berada di titik 2 sebesar 1,27 m/s. Perbedaan tekanan udara dan arah angin merupakan faktor yang menentukan nilai kecepatan angin (Yulianti, 2014). Pengukuran kelembaban pada hari Minggu di pagi hari titik 3 memiliki nilai kelembaban tertinggi yaitu sebesar 74\% RH sedangkan pada siang dan sore hari nilai kelembaban paling tinggi berada di titik 1 yaitu masing masing $59 \%$ RH dan $57 \%$ RH. Pada hari Senin titik 3 merupakan titik yang memiliki nilai kelembaban paling tinggi pada pagi hari yaitu $74 \% \mathrm{RH}$, titik 1 memiliki nilai kelembaban tertinggi pada siang dan sore hari sebesar $59 \%$ RH. Menurut Harahap, Marsaulina \& Ashar (2013) salah satu faktor yang menentukan nilai kelembaban adalah suhu, ketika suhu udara rendah maka kelembaban udara akan meningkat dan begitu sebaliknya.

\subsection{Konsentrasi Karbon Monoksida (CO) di Udara Ambien}

Berdasarkan "Peraturan Gubernur Kalimantan Selatan No 53 Tahun 2007”, baku mutu gas CO di udara ambien adalah $20.000 \mu \mathrm{g} / \mathrm{Nm}^{3}$ untuk waktu pengukuran $1 \mathrm{jam}$. Dari hasil pengukuran diperoleh konsentrasi gas CO berbeda-beda setiap jam dan titik sampling. Konsentrasi CO pada hari 
Minggu yang mewakili hari libur pada pagi hari paling tinggi berada di titik 1 yaitu sebesar 824 $\mu \mathrm{g} / \mathrm{Nm} 3$ kemudian di titik 2 sebesar $738 \mu \mathrm{g} / \mathrm{Nm}^{3}$, dan yang paling rendah adalah di titik 3 sebesar $607 \mu \mathrm{g} / \mathrm{Nm} 3$, pada siang hari ketiga titik memiliki konsentrasi CO yang sama yaitu $458 \mu \mathrm{g} / \mathrm{Nm}^{3}$ sedangkan pada sore hari konsentrasi tertinggi berada pada titik 1 sebesar $763 \mu \mathrm{g} / \mathrm{Nm}^{3}$ kemudian dititik 3 sebesar $595 \mu \mathrm{g} / \mathrm{Nm}^{3}$ dan konsentrasi CO terendah pada titik 2 sebesar $458 \mu \mathrm{g} / \mathrm{Nm}^{3}$. Berikut hasil uji laboratorium parameter karbon monoksida $(\mathrm{CO})$ dapat dilihat pada Gambar 4 dan 5.

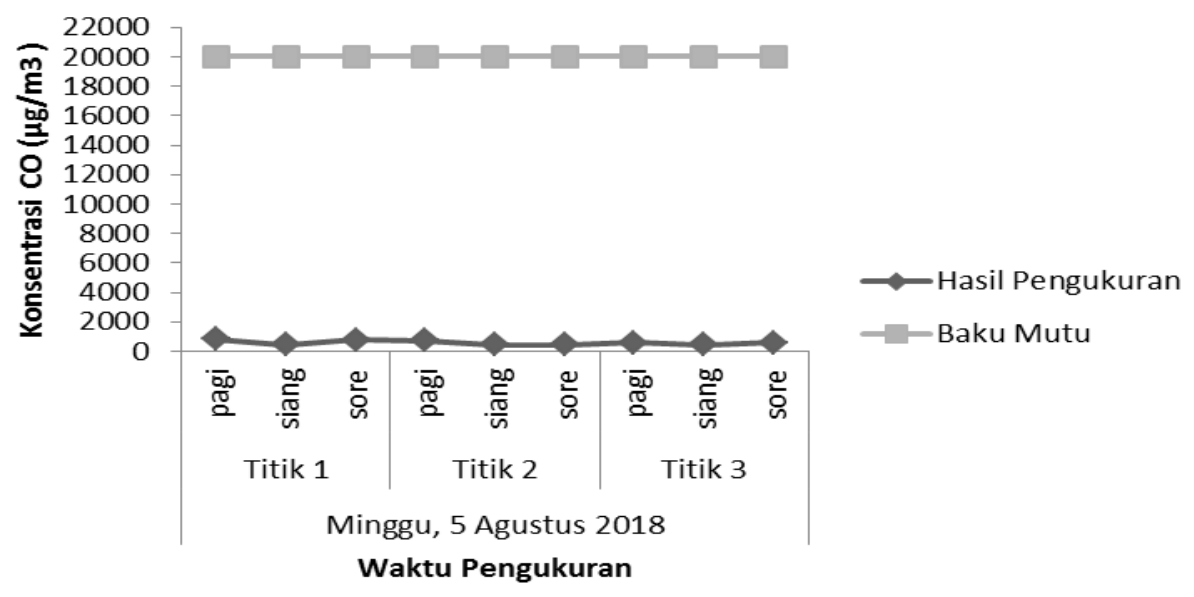

Gambar 4. Pengukuran CO Minggu, 5 Agustus 2018

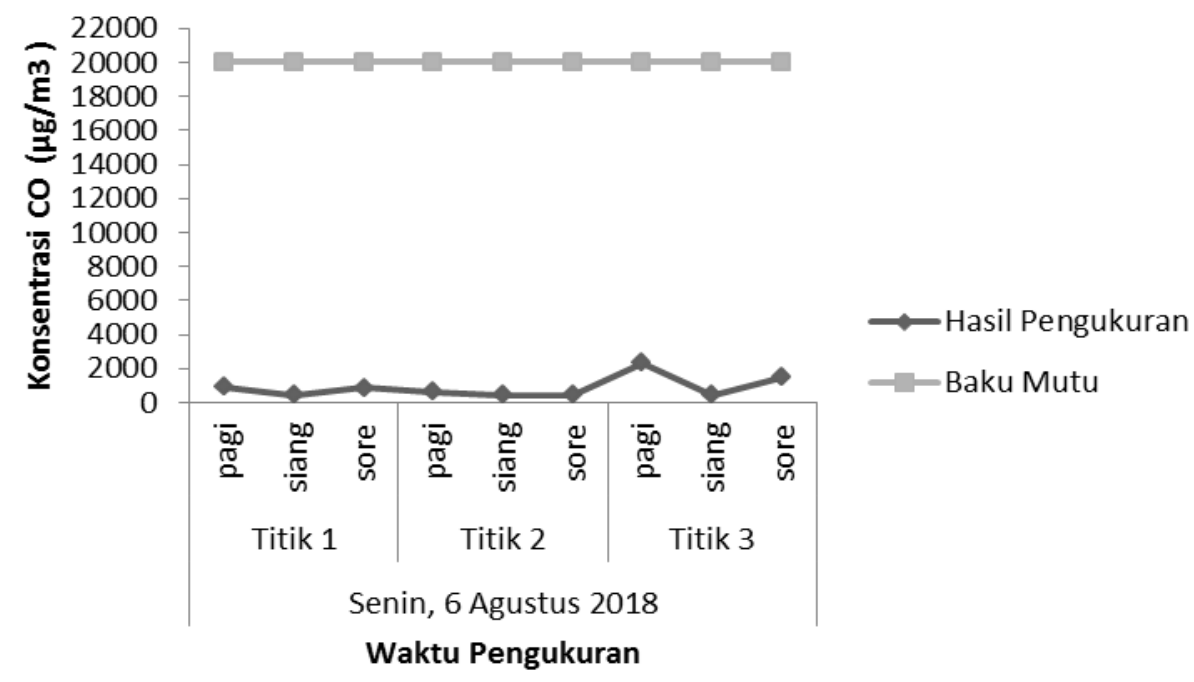

Gambar 5. Pengkuran CO Senin, 6 Agustus 2018

Hasil pengukuran pada hari Senin yang mewakili hari kerja konsentrasi CO tertinggi pada pagi hari yaitu dititik 3 sebesar $2.358 \mu \mathrm{g} / \mathrm{Nm}^{3}$ kemudian di titik 1 sebesar $927 \mu \mathrm{g} / \mathrm{Nm}^{3}$, dan yang paling rendah adalah di titik 2 sebesar $658 \mu \mathrm{g} / \mathrm{Nm}^{3}$, pada siang hari ketiga titik memiliki konsentrasi CO yang sama yaitu $458 \mu \mathrm{g} / \mathrm{Nm}^{3}$ sedangkan pada sore hari konsentrasi tertinggi berada pada titik 3 sebesar $1.499 \mu \mathrm{g} / \mathrm{Nm}^{3}$ kemudian dititik 1 sebesar $876 \mu \mathrm{g} / \mathrm{Nm}^{3}$ dan konsentrasi CO terendah pada titik 2 sebesar $458 \mu \mathrm{g} / \mathrm{Nm}^{3}$.

Karbon monoksida memiliki sifat tidak berbau, tidak berwarna, tidak berasa (Ratnawati, Widowati, \& Gunawan, 2012). Proses pembakaran bahan bakar fosil merupakan sumber utama pencemar karbon, salah satunya berasal dari kendaraan bermotor. Kontribusi dari gas buangan kendaraan bermotor tersebut mencapai 60-70\% (Pangerapan, Sumampouw, \& Joseph, 2018). Tingginya 
konsentrasi gas CO pada pagi hari dan sore hari disebabkan karena kepadatan lalu lintas yang lebih tinggi dibandingkan pada siang hari karena adanya aktivitas masyarakat pada pagi dan sore hari yaitu berangkat kerja dan sekolah begitu sebaliknya pada waktu sore hari. Tingginya arus lalu lintas pada pagi dan sore hari sering mengakibatkan terjadinya kemacetan, kemacetan tersebut berdasarkan studi observasi salah satunya diakibatkan karena di lokasi tersebut lebar jalan hanya sekitar $4 \mathrm{~m}$ dan jalan tidak digunakan sesuai fungsinya yaitu sebagai jalan lingkungan sekunder yang hanya dilalui kendaraan kecil tetapi juga dilewati oleh kendaraan berat, selain itu seringnya kendaraan berhenti dan parkir di badan jalan juga dapat menimbulkan kemacetan. Kemacetan lalu lintas merupakan salah satu faktor utama terjadinya peningkatan konsentrasi gas $\mathrm{CO}$ di udara. Hoesodo (2004), menyatakan emisi gas buang kendaraan dalam kondisi macet menghasilkan gas CO 12 kali lebih tinggi dibandingkan pada kondisi jalan yang lancar.

Gas karbon monoksida (CO) dari kendaraan berbahan bakar bensin sebesar $1 \%$ diwaktu bergerak dan 7\% diwaktu tidak bergerak, kendaraan berbahan bakar solar gas buang CO yang dihasilkan sebanyak 0,2\% apabila bergerak dan 4\% pada kendaraan berhennti (Pangerapan et al., 2018). Hasil penelitian Rahmawati (2008), dengan judul penelitian pola Spasial konsentrasi CO di kota Jakarta menyatakan adanya hubungan positif antara konsentrasi kadar $\mathrm{CO}$ dengan arus lalu lintas. Selain itu, keberadaan sungai Kuin yang masih digunakan masyarakat sebagai jalur transportasi air diperkirakan juga berkontribusi terhadap konsentrasi karbon monoksida di udara ambien. Sumber emisi dari transportasi air meliputi semua angkutan di sungai atau laut seperti kapal rekreasi berukuran kecil di danau atau sungai atau kapal barang berukuran besar kelas samudera (KLH, 2012). Adanya dominasi bahan bakar dalam ruang pembakaran transportasi air tersebut sehingga menyebabkan terbentuknya gas CO pada gas buang (VA, Arthana, \& Suyasa, 2015).

Selain faktor lalu lintas, faktor meteorologi juga berpengaruh terhadap konsentrasi CO di udara ambien, pada penelitian ini dilakukan pengukuran seperti kecepatan angin suhu dan kelembaban di lokasi penelitian. Hasil pengukuran meteorologi berupa suhu, kecepatan angin dan kelembaban di lokasi penelitian pada hari Minggu, rata-rata kecepatan angin di titik 1 sebesar $1,266 \mathrm{~m} / \mathrm{s}$, suhu $30^{\circ} \mathrm{C}$ dan kelembaban $60 \%$ RH. Pada titik 2 rata-rata kecepatan angin sebesar $3,760 \mathrm{~m} / \mathrm{s}$, suhu $33^{\circ} \mathrm{C}$ dan kelembaban $45 \%$ RH. Sedangkan pada titik 3 rata-rata kecepatan angin sebesar $0.883 \mathrm{~m} / \mathrm{s}$ dengan suhu $32^{\circ} \mathrm{C}$ dan kelembaban $58 \% \mathrm{RH}$. Pada hari Senin rata-rata kecepatan angin di titik 1 sebesar $0,650 \mathrm{~m} / \mathrm{s}$, suhu $29^{\circ} \mathrm{C}$ dan kelembaban $58 \% \mathrm{RH}$. Pada titik 2 rata-rata kecepatan angin sebesar 1,043 $\mathrm{m} / \mathrm{s}$, suhu $33^{\circ} \mathrm{C}$ dan kelembaban $50 \%$ RH. Sedangkan pada titik 3 rata-rata kecepatan angin sebesar $0,146 \mathrm{~m} / \mathrm{s}$ dengan suhu $31^{\circ} \mathrm{C}$ dan kelembaban 57\% RH. Menurut Rahmawati (2008) semakin cepat kecepatan angin akan menimbulkan pengenceran dan menyebabkan konsentrasi polutan udara di wilayah tersebut berkurang. Kecepatan angin akan menentukan penyebaran dan sejauh mana karbon monoksida diangkut dan disebarkan serta akan membawa ke area lain searah dengan arah angin, makin besar kecepatan angin makin kecil konsentrasi karbon monoksida di daerah tersebut. Suhu udara yang tinggi akan menyebabkan konsentrasi pencemar menjadi makin rendah, sedangkan pengaruh kelembaban terhadap konsentrasi pencemar yaitu semakin tinggi kelembaban maka dapat meningkatkan kadar polutan di udara (Harahap et al., 2013).

Dapat dilihat dari Gambar 4 dan Gambar 5 hasil pengukuran di hari libur dan di hari kerja konsentrasi gas karbon monoksida meningkat pada pagi hari kemudian mengalami penurunan di siang hari dan kembali meningkat pada sore hari, tetapi konsentrasi karbon monoksida di ketiga titik penelitian masih berada dibawah $4000 \mu \mathrm{g} / \mathrm{Nm}^{3}$. Nilai tersebut tidak melewati baku mutu menurut "Peraturan Gubernur Kalimantan Selatan No 53 Tahun 2007" dengan lama pengukuran 1 jam. Hasil yang diperoleh dari penelitian ini sesuai dengan penelitian dari Muzzayid (2014) tentang 
studi konsentrasi kadar $\mathrm{CO}$ di jalan pettarani kota makasar. Hasil pengukurannya menunjukkan bahwa konsentrasi karbon monoksida (CO) meningkat pada pagi hari, dan berada dibawah baku mutu udara ambien berdasarkan "PP RI NO 41 Tahun 1999" sebesar $30.000 \mu \mathrm{g} / \mathrm{Nm}^{3}$. Walaupun penelitian ini menunjukkan konsentrasi kadar karbon monoksida dibawah standar baku mutu, namun pemantauan karbon monoksida perlu dilakukan secara berkala karena gas CO merupakan salah satu gas yang dapat berdampak negatif pada kesehatan manusia, yaitu dapat memengaruhi kerja jantung, sistem syaraf pusat, dan organ tubuh yang peka oleh kekurangan oksigen (Arisnawati, Riduan, \& Annisa, 2017).

\subsection{Konsentrasi Nitrogen Dioksida $\left(\mathrm{NO}_{2}\right)$ di Udara Ambien}

Berikut hasil uji laboratorium parameter nitrogen dioksida $\left(\mathrm{NO}_{2}\right)$ dapat dilihat pada gambar :

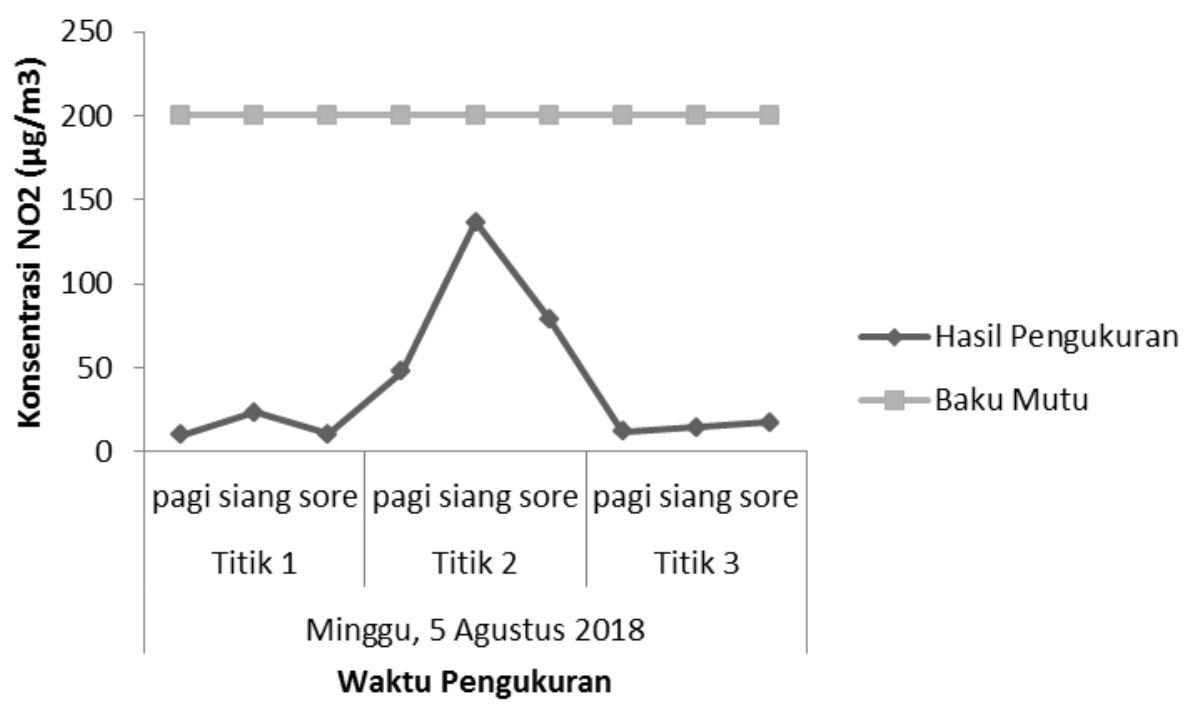

Gambar 6. Pengukuran $\mathrm{NO}_{2}$ Minggu, 5 Agustus 2018

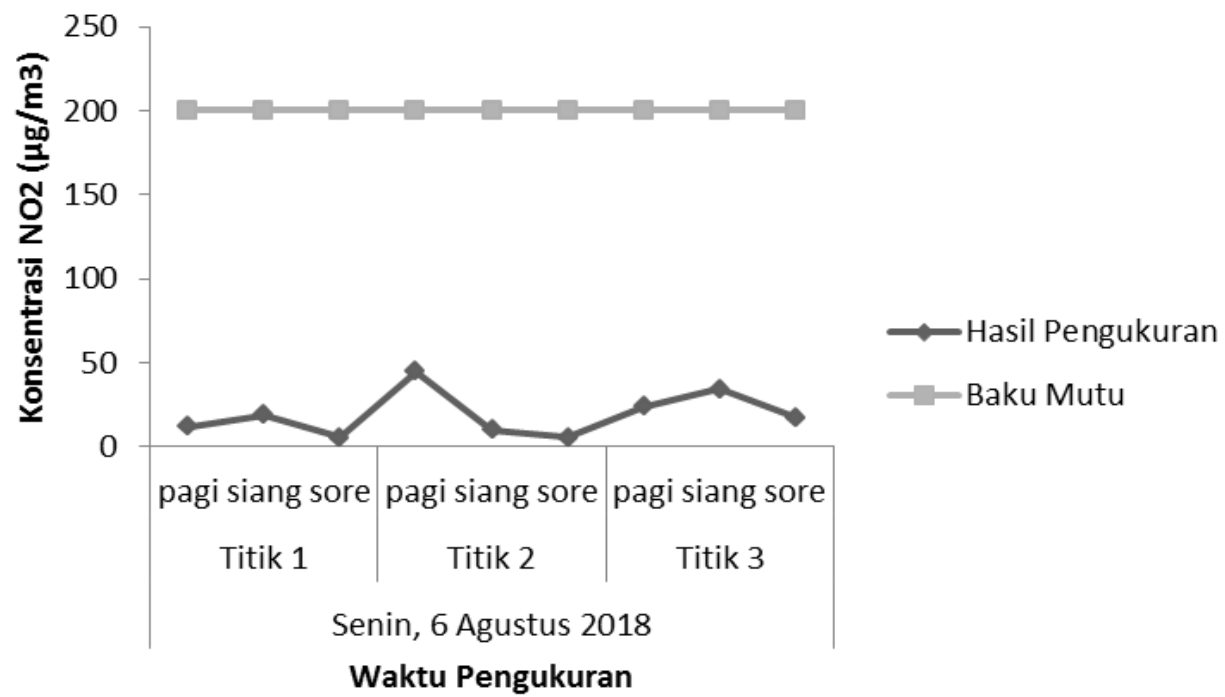

Gambar 7. Pengkuran $\mathrm{NO}_{2}$ Senin, 6 Agustus 2018 
Berdasarkan "Peraturan Gubernur Kalimantan Selatan No 53 Tahun 2007”, baku mutu gas $\mathrm{NO}_{2}$ di udara ambien sebesar $200 \mu \mathrm{g} / \mathrm{Nm}^{3}$ untuk waktu pengukuran selama 1 jam. Hasil pengukuran konsentrasi $\mathrm{NO}_{2}$ pada hari Minggu yang mewakili hari libur pada pagi hari didapatkan konsentrasi tertinggi pada titik 2 yaitu sebesar $47,7 \mu \mathrm{g} / \mathrm{Nm}^{3}$ kemudian di titik 3 sebesar $12 \mu \mathrm{g} / \mathrm{Nm}^{3}$, dan yang paling rendah adalah di titik 1 sebesar $10,2 \mu \mathrm{g} / \mathrm{Nm}^{3}$, pada siang hari konsentrasi $\mathrm{NO}_{2}$ paling tinggi di titik 2 yaitu sebesar 136,7 $\mu \mathrm{g} / \mathrm{Nm}^{3}$ kemudian dititik 1 sebesar $23,5 \mu \mathrm{g} / \mathrm{Nm}^{3}$ dan terendah berada pada titik 3 sebesar $14,2 \mu \mathrm{g} / \mathrm{Nm}^{3}$ sedangkan pada sore hari konsentrasi tertinggi berada pada titik 2 sebesar 79,2 $\mu \mathrm{g} / \mathrm{Nm}^{3}$ kemudian dititik 3 sebesar 17,6 $\mu \mathrm{g} / \mathrm{Nm}^{3}$ dan konsentrasi $\mathrm{NO}_{2}$ terendah pada titik 1 sebesar 10,6 $\mu \mathrm{g} / \mathrm{Nm}^{3}$. Hasil pengukuran pada hari Senin yang mewakili hari kerja konsentrasi $\mathrm{NO}_{2}$ tertinggi pada pagi hari yaitu dititik 2 sebesar $44,6 \mu \mathrm{g} / \mathrm{Nm}^{3}$ kemudian di titik 3 sebesar 23,7 $\mu \mathrm{g} / \mathrm{Nm}^{3}$, dan yang paling rendah adalah di titik 1 sebesar $12,1 \mu \mathrm{g} / \mathrm{Nm}^{3}$, pada siang hari konsentrasi $\mathrm{NO}_{2}$ paling tinggi di titik 3 yaitu sebesar 34,5 $\mu \mathrm{g} / \mathrm{Nm}^{3}$ kemudian dititik 1 sebesar $19 \mu \mathrm{g} / \mathrm{Nm}^{3}$ dan terendah berada pada titik 2 sebesar $10,1 \mu \mathrm{g} / \mathrm{Nm}^{3}$ sedangkan pada sore hari konsentrasi tertinggi berada pada titik 3 sebesar 17,6 $\mu \mathrm{g} / \mathrm{Nm}^{3}$ kemudian dititik 1 dan 2 memiliki konsentrasi yang sama yaitu sebesar $5,7 \mu \mathrm{g} / \mathrm{Nm}^{3}$.

Menurut Herawati (2018) gas nitrogen dioksida adalah gas yang lebih beracun dibandingkan dengan jenis Nitrogen Oksida lain di udara. Salah satu gas yang dihasilkan dari hasil pembakaran kendaraan bermotor adalah gas NOx. Dapat dilihat pada gambar 6 dan gambar 7 fluktuasi konsentrasi yang dihasilkan selama dua hari pengukuran. Kecepatan kendaraan berpengaruh terhadap emisi gas $\mathrm{NO}_{2}$ yang dihasilkan. Semakin meningkatnya kecepatan kendaraan maka konsentrasi gas $\mathrm{NO}_{2}$ juga akan meningkat, perubahan konsentrasi $\mathrm{NO}_{2}$ terlihat jelas pada saat mobil bergerak dari kecepatan sedang kekecepatan tinggi. Usia kendaraan, perawatan mesin, kelancaran lalu lintas, cara mengemudi, dan perbedaan penggunaan bahan bakar dapat mempengaruhi konsentrasi $\mathrm{NO}_{2}$ yang dihasilkan. Pada kendaraan berbahan berbahan bakar bensin, perubahan konsentrasi gas $\mathrm{NO}_{2}$ meningkat jelas saat kendaraan mulai melaju dengan kecepatan sedang (40- 60 $\mathrm{km} / \mathrm{jam}$ ), sedangkan kendaraan yang menggunakan bakar solar telah menghasilkan konsentrasi gas $\mathrm{NO}_{2}$ yang relatif tinggi saat kondisi diam, namun kenaikannya terhadap variasi kecepatan kendaraan tidak begitu signifikan (Bachtiar, 2005). Sama seperti konsentrasi CO, konsentrasi $\mathrm{NO}_{2}$ yang dihasilkan juga diperkirakan dipengaruhi oleh adanya aktivitas transportasi di sungai Kuin. Menurut Risky (2015) NOx pada kapal terbentuk akibat dari proses pembakaran di ruang bakar yang kelebihan jumlah oksigen, maka semakin tinggi oksigen pada gas buang semakin tinggi juga Nox yang terbentuk. NOx sangat tidak stabil dan jika terlepas ke udara bebas akan berkaitan dengan oksigen dan membentuk $\mathrm{NO}_{2}$.

Faktor meteorologi dapat memberikan pengaruh terhadap konsentrasi pencemar NO2 di udara ambien seperti pengenceran, penyebaran, dan lain-lain. Hasil pengukuran meteorologi berupa suhu, kecepatan angin dan kelembaban di lokasi penelitian pada hari Minggu, rata-rata kecepatan angin di titik 1 sebesar $1,266 \mathrm{~m} / \mathrm{s}$, suhu $30 \mathrm{oC}$ dan kelembaban $60 \% \mathrm{RH}$. Pada titik 2 rata-rata kecepatan angin sebesar $3,760 \mathrm{~m} / \mathrm{s}$, suhu $33 \mathrm{oC}$ dan kelembaban $45 \% \mathrm{RH}$. Sedangkan pada titik 3 rata-rata kecepatan angin sebesar $0,883 \mathrm{~m} / \mathrm{s}$ dengan suhu 320C dan kelembaban $58 \%$ RH. Pada hari Senin rata-rata kecepatan angin di titik 1 sebesar $0,650 \mathrm{~m} / \mathrm{s}$, suhu $29 \mathrm{oC}$ dan kelembaban $58 \% \mathrm{RH}$. Pada titik 2 rata-rata kecepatan angin sebesar $1,043 \mathrm{~m} / \mathrm{s}$, suhu $33 \mathrm{oC}$ dan kelembaban $50 \% \mathrm{RH}$. Sedangkan pada titik 3 rata-rata kecepatan angin sebesar $0,146 \mathrm{~m} / \mathrm{s}$ dengan suhu 31 oC dan kelembaban 57\% RH. Jika dilihat dari pengaruh suhu, konsentrasi NO2 tertinggi pada hari minggu terjadi di siang hari berada di titik 2 yaitu sebesar $136,7 \mu \mathrm{g} / \mathrm{Nm} 3$ dengan suhu tertinggi dibandingkan dengan titik yang lain yaitu $33 \mathrm{oC}$ dan pada hari senin terjadi pada pagi hari dititik 2 
sebesar 44,6 $\mu \mathrm{g} / \mathrm{Nm} 3$ dengan suhu tertinggi dibandingkan dengan titik yang lain yaitu 32oC .Hal ini menunjukkan semakin tinggi suhu udara maka konsentrasi NO2 semakin tinggi pula. Penurunan konsentrasi $\mathrm{NO}_{2}$ terjadi saat kecepatan angin tinggi, begitu juga sebaliknya. Dapat dilihat pada pengukuran NO2 di hari senin pada sore hari paling tinggi berada pada titik 3 sebesar 17,6 $\mu \mathrm{g} / \mathrm{Nm} 3$ dengan rata-rata kecepatan angin paling rendah dibandingkan dengan titik lain yaitu $0.146 \mathrm{~m} / \mathrm{s}$. Rendahnya kecepatan angin menyebabkan penyebaran udara menjadi lambat dan terakumulasi di sekitar lokasi penelitian sehingga konsentrasi $\mathrm{NO}_{2}$ menjadi tinggi, sedangkan semakin tinggi kecepatan angin maka konsentrasi $\mathrm{NO}_{2}$ yang dihasilkan akan semakin kecil karena polutan terbawa angin menjauhi lokasi pengukuran. Pengaruh kelembaban pada konsentrasi pencemar yakni apabila kelembaban meningkat maka dapat meningkatkan konsentrasi pencemar di udara ambien.

Berdasarkan Gambar 6 dan gambar 7 data konsentrasi $\mathrm{NO}_{2}$ baik di hari Minggu maupun hari Senin pada ketiga lokasi sampling berada di bawah baku mutu. Hal ini menunjukkan bahwa gas $\mathrm{NO}_{2}$ saat ini tidak menimbulkan dampak buruk bagi kesehatan manusia dan berada dibawah nilai ambang batas yang ditentukan berdasarkan "Peraturan Gubernur Kalimantan Selatan No 53 Tahun 2007" yaitu $200 \mu \mathrm{g} / \mathrm{Nm}^{3}$. Dampak yang ditimbulkan dari konsentrasi gas NO2 yang tinggi, dapat mengakibatkan peradangan paru-paru.

\section{KESIMPULAN DAN SARAN}

\subsection{Kesimpulan}

Hasil pengukuran menunjukan konsentrasi karbonmonoksida $(\mathrm{CO})$ dan nitrogen dioksida $\left(\mathrm{NO}_{2}\right)$ di ketiga titik lokasi penelitian belum melalui nilai ambang batas atau masih memenuhi baku mutu berdasarkan "Peraturan Gubernur Kalimantan Selatan No 53 Tahun 2007" baku mutu parameter CO sebesar $20.000 \mu \mathrm{g} / \mathrm{Nm}^{3}$ sedangkan parameter $\mathrm{NO}_{2}$ sebesar $200 \mu \mathrm{g} / \mathrm{Nm}^{3}$. Hal tersebut terjadi baik di hari Minggu yang mewakili hari libur maupun di hari Senin yang mewakili hari kerja.

\subsection{Saran}

Dari hasil penelitian yang dilakukan yaitu kadar $\mathrm{CO}$ dan $\mathrm{NO}_{2}$ di ruas jalan Kuin Utara dan Kuin Selatan Kota Banjarmasin masih berada dibawah baku mutu, namun untuk mengontrol kondisi udara agar tetap stabil dan tidak tercemar perlu disarankan kepada pemerintah untuk melaksanakan pemantauan lingkungan secara rutin dan meningkatkan penghijauan di sekitar kawasan tersebut untuk menekan penyebaran gas pencemar udara. Kepada masyarakat sekitar hendaknya tetap menggunakan masker ketika beraktivitas sebagai upaya pencegahan terhadap gangguan kesehatan khususnya pernafasan.

\subsection{Ucapan Terima Kasih}

Penulis mengucapkan terima kasih kepada Allah SWT atas rahmat dan karunia yang telah diberi selama ini. Terima kasih kepada orang tua yang telah memberikan semangat dan do'a. Penulis juga mengucapkan terimakasih kepada Ibu Nova Annisa, S.Si., MS serta kepada bapak Dr. Rony Riduan, ST., MT dan bapak Dr. Hafiizh Prasetia, S.Si., MS sebagai pembimbing. Terima kasih kepada semua pihak yang tidak dapat saya sebutkan satu persatu.

\section{DAFTAR PUSTAKA}

Arifiyanti, F. (2013). Pengaruh Kelembaban, Suhu, Arah Dan Kecepatan Angin Terhadap Konsentrasi Karbon Monoksida (CO) dengan Membandingkan Dua Volume Sumber Pencemar di Area Pabrik dan di Persimpangan Jalan (Studi Kasus: PT. Inti General Yaja Steel dan Persimpangan Jrakah). Jurnal Teknik Lingkungan, 2(1), 1-10.

Arisnawati, R. S., Riduan, R., \& Annisa, N. (2017). Pemetaan Distribusi Konsentrasi Karbon 
Monoksida (CO) Dihubungkan Dengan Aktivitas Kendaraan Bermotor Di Kampus Universitas Lambung Mangkurat Banjarbaru. Jernih: Jurnal Tugas Akhir Mahasiswa Program Studi Teknik Lingkungan, 1(01).

Bachtiar, V. S. (2005). Kajian Hubungan Antara Variasi Kecepatan Kendaraan dengan Emisi yang dikeluarkan pada Kendaraan Bermotor Roda Empat'. Jurnal, 2.

Bachtiar, V. S. (2013). Studi Paparan Konsentrasi Gas Karbonmonoksida (CO) di Lingkungan Kerja Petugas Parkir Dan Polisi Lalu Lintas Di Kota Padang. Jurnal Dampak, 10(1), 60-72.

Badan Standarisasi Nasional. (2005). SNI 19-7119.9-2005 Tentang Udara Ambien- Bagian 9 Penentuan Lokasi Pengambilan Contoh Uji Pemantauan Kualitas Udara Roadside.

Badan Standarisasi Nasional. (2011). SNI 7119.10-2011 Tentang Udara Ambien-Bagian 10 Cara Uji Kadar Karbon Monoksida (CO) Menggunakan Metode Non Dispersive Infra Red (NDIR).

Damara, D. Y., Wardhana, I. W., \& Sutrisno, E. (2017). Analisis Dampak Kualitas Udara Karbon Monoksida (Co) di Sekitar Jl. Pemuda Akibat Kegiatan Car Free Day Menggunakan Program Caline4 dan Surfer (Studi Kasus: Kota Semarang). Jurnal Teknik Lingkungan, 6(1), 1-14.

Fariya, S., \& Rejeki, S. (2015). SEACELL (Sea Water Electrochemical cell) Pemanfaatan Elektrolit Air Laut Menjadi Cadangan Sumber Energi Listrik Terbarukan Sebagai Penerangan Pada Sampan. Jurnal Sain Dan Teknologi, 10(1), 44-58.

Goembira,F., Surianti, I., \& Ihsan, T. (2014). Prediksi Tingkat Emisi Gas Karbon Dioksida (Co2) Dari Kegiatan Transportasi Akibat Beroperasinya Rumah Sakit Pendidikan Di Kampus Universitas Andalas Limau Manis. Jurnal Dampak, 11(2), 110-126.

Harahap, Y. Y., Marsaulina, I., \& Ashar, T. (2013). Perbandingan Kadar Karbon Monoksida (CO) dan Nitrogen Dioksida (NO2) di Udara Ambien Berdasarkan Keberadaan Pohon Angsana (Pterocarpus indicus) di Beberapa Jalan Raya di Kota Medan Tahun 2012. Lingkungan Dan Keselamatan Kerja, 2(3).

Herawati, P., Riyanti, A., \& Pratiwi, A. (2018). Hubungan Konsetrasi NO2 Udara Ambien Terhadap Konsentrasi NO2 Udara Dalam Ruang Di Lampu Merah Simpang Jelutung Kota Jambi. Jurnal Daur Lingkungan, 1(1), 1-4.

Hidup, K. L. (2012). Pedoman Penyelenggaraan Inventarisasi Gas Rumah Kaca Nasional, Buku II Pedoman Umum. Jakarta (ID): KLH.

Hoesodo, D. (2004). Permodelan Pencemaran Udara Akibat Lalu Lintas di Jalan Arteri (Studi Kasus Ruas Jalan Soekarno-Hatta di Kota Bandung). Program Pascasarjana Universitas Diponegoro.

Pangerapan, S. B., Sumampouw, O. J., \& Joseph, W. B. S. (2018). ANALISIS KADAR KARBON MONOKSIDA (CO) UDARA DI TERMINAL BERIMAN KOTA TOMOHON TAHUN 2018. KESMAS, 7(3).

Peraturan Gubernur Kalimantan Selatan. (2007). Nomor 53 Tahun 2007 Tentang Baku Mutu Udara dan Kebisingan.

Rahmawati, M. (2008). Pola Spasial Gas Karbon Monoksida (CO) di Kota Jakarta. Universitas Indonesia. Jakarta.

Ratnawati, H., Widowati, W., \& Gunawan, E. (2012). Hubungan antara kadar karbon monoksida (CO) udara dan tingkat kewaspadaan petugas parkir di tiga jenis tempat parkir. Jurnal Kedokteran Maranatha, 10(1).

Roza, V., Ilza, M., \& Anita, S. (2015). Korelasi Konsentrasi Particulate Matter (PM10) di Udara dan Kandungan Timbal $(\mathrm{Pb})$ dalam Rambut Petugas SPBU di Kota Pekanbaru. Dinamika Lingkungan, 2(1), 52-60.

Sari, R. P. (2008). Pergeseran Pergerakan Angkutan Sungai di Sungai Martapura Kota Banjarmasin. PROGRAM PASCA SARJANA UNIVERSITAS DIPONEGORO.

VA, D. P. R., Arthana, I. W., \& Suyasa, I. W. B. (2015). Inventarisasi Emisi Sumber Bergerak Dari 
Transportasi Laut (Non-Road) Di Wilayah Pesisir Kota Denpasar. Ecotrophic: Jurnal Ilmu Lingkungan (Journal of Environmental Science), 9(1), 10-18.

Yulianti, S. (2014). Analisis konsentrasi gas Karbon Monoksida (CO) pada ruas Jalan Gajah Mada Pontianak. Jurnal Mahasiswa Teknik Lingkungan UNTAN, 1(1). 